\title{
The CRC in South Africa 15 years on: does the new Child Justice Act 75 of 2008 comply with international children's rights instruments?
}

\author{
LORENZO W AKEFIELD*
}

\author{
Researcher, Children's Rights Project, Community Law Centre, \\ University of the Western Cape
}

\begin{abstract}
$\underline{\text { Abstract }}$
Article 40 of the United Nations Convention on the Rights of the Child ${ }^{1}$ requires states parties to take appropriate measures to ensure that children accused of committing offences are treated in a manner that would ensure that their best interests are upheld. South Africa ratified the CRC in 1995, the provisions of which have influenced the children's rights clause in its 1996 Constitution. Section 28(1)(g) of the Constitution stipulates that children may not be detained, except as a measure of last resort and, should they be detained, it should be for the shortest appropriate period of time. Section 28(1)(g) goes further to give domestic effect to the following guarantees stipulated in Article 40 of the CRC: (1) the right to be treated in a manner, and kept in conditions, that take account of the child's age; and (2) to have a legal practitioner assigned to the child. Recently, SA has enacted its Child Justice Act 75 of 2008, which came into operation on 1 April 2010. The question to be covered in this article is whether this Act truly complies with the international standards set by the CRC (15 years after $S A$ ratified it); the general comments by the United Nations Committee on the Rights of the Child ${ }^{3}$ and other non-binding, yet persuasive instruments like the Standard Minimum Rules on the Administration of Juvenile Justice and the United Nations Rules for the Protection of Juveniles Deprived of their Liberty. This article only examines four aspects of the Child Justice Act, being: criminal capacity; pretrial release and detention; diversion; and sentencing. It concludes that, but for a few technical aspects of the Child Justice Act, $S A$ took significant steps to comply with its international obligations when it domesticated the CRC in relation to children who commit offences.
\end{abstract}

\section{Introduction}

$\mathrm{D}$ uring 1995 the Republic of SA ratified the United Nations CRC. This Convention would in essence require the government of SA to harmonise its provisions in order to comply with the international standards and obligations created. After the ratification of this instrument the government set out on a process of harmonisation by instructing the

\footnotetext{
* I would like to acknowledge with appreciation the financial support for this paper provided by the Ford Foundation. The views expressed in this article do not necessarily represent the official views of the Ford Foundation. I would also like to acknowledge Professor Julia Sloth-Nielsen and Professor Jacqui Gallinetti for their valuable comments on previous drafts.

1 The United Nations Convention on the Rights of the Child was adopted by the General Assembly on 20 November 1989 and entered into force on 2 September 1990. Hereinafter referred to as CRC.

2 Hereinafter referred to as SA.

3 Hereinafter referred to as the Committee.
} 
South African Law Commission (SALRC) ${ }^{4}$ to investigate the extent of the existing legislation's compliance with the CRC. At the same time, this harmonisation period had to take into account the advances already made in relation to children's rights by both the interim ${ }^{5}$ and $1996^{6}$ constitutions of SA.

Apart from investigating the extent to which the then Child Care Act $^{7}$ and other legislation, such as like the Children's Status Act, ${ }^{8}$ complied with the Constitution and international law, the SALRC was also tasked with investigating whether the provisions in the current Criminal Procedure Act $^{9}$ and other criminal procedural laws complied with the Constitution and international law for children who come into conflict with the law. The result of both these processes was a complete legislative overhaul which saw the enactment of the Children's Act, ${ }^{10}$ the Children's Amendment Act ${ }^{11}$ and the Child Justice Act. ${ }^{12}$ This article will assess whether the Child Justice Act complies with the CRC and other international treaties and rules to which SA is a party/signatory. This article will first assess the international framework against which compliance will be judged, before giving an overview of the Child Justice Act. Once this is completed, an analysis of four provisions in the Child Justice Act will be investigated. These four provisions relate to criminal capacity, detention and release, diversion, and sentencing of children under the Child Justice Act. A conclusion will follow.

This article will only assess the substantive provisions and will not delve into the practical implications of the Child Justice Act, as this Act is only a few months into operation at the time of writing.

\section{International framework}

In light of the international child justice standards found within the CRC, multiple initiatives were undertaken before the adoption of this treaty and in parallel with its development. These include both the United Nations Standard Minimum Rules for the Administration of Juvenile Justice, ${ }^{13}$ the United Nations Guidelines for the Prevention of Juvenile Delinquency ${ }^{14}$ and the United Nations Rules for the Protection of Juveniles Deprived of their Liberty. ${ }^{15}$ Even though all three of these instruments are of a nonbinding nature (based on the fact that they are declarations and not treaties) they do hold great persuasive weight.

The CRC was the first treaty that solely focused on codifying the rights of children in an international arena. Adopted on 20 November 1989, the CRC came into force on 2 September 1990. This comprehensive treaty contains 54 articles which cover a wide range

4 At that time, it was known as the South African Law Commission. Now it is known as the South African Law Reform Commission. This commission is tasked with doing research on creating new legislation. Hereinafter referred to as the SALRC.

5 S. 30 of the Interim Constitution of the Republic of South Africa, Act 200 of 1993.

6 S. 28 of the Constitution of the Republic of South Africa, Act 108 of 1996. Hereinafter referred to as the Constitution.

7 Act 74 of 1983 . This Act dealt with the care and protection of children in SA.

8 Act 82 of 1987.

9 Act 51 of 1977.

10 Act 38 of 2005 .

11 Act 41 of 2007.

12 Act 75 of 2008 .

13 GA Res. 40/33 of 29 November 1985. Hereinafter referred to as the Beijing Rules.

14 GA Res. 45/ 112 of 14 December 1990. Hereinafter referred to as the Riyadh Guidelines.

15 GA Res. 45/ 113 of 14 December 1990. Hereinafter referred to as the JDL Minimum Standards. 
of topics including: Article 37, that deals broadly with children deprived of their liberty and the prevention of torture; Article 39, that deals with the physical and psychological recovery and social reintegration of children; and Article 40, which calls for a criminal justice system that is suitable for children who come into conflict with the law.

Article 43 of the CRC establishes a Committee on the Rights of the Child ${ }^{15}$ which is tasked with monitoring the implementation of the CRC in domestic laws by countries that have ratified this treaty. A duty of this Committee is to produce general comments which provide states parties to the CRC with recommendations on how specific provisions should be interpreted. During 2007, at its 45th session the Committee released General Comment No. 10 that deals with Children's Rights in Juvenile Justice. In light of creating a criminal justice system that is compliant with the CRC and in the best interests of children, the provisions of General Comment No. 10 play a vital role in interpreting Articles 37 and 40 of the CRC.

\section{The Child Justice Act: historical background and overview}

SA saw the start of an overhaul of the child justice system during 1995 when the then Minister of Justice, advocate Dullah Omar, ${ }^{16}$ instructed the SALRC to investigate and propose a Draft Bill for children who come into conflict with the law. After publishing issue and discussion papers on juvenile justice, the SALRC published an extensive report on juvenile justice and a draft Bill, ${ }^{17}$ which was sent to the Department of Justice during July 2000, where it remained for two years before being tabled in Parliament. The draft Bill was introduced into Parliament as the Child Justice Bill 49 of 2002.

In Parliament the contents of the Child Justice Bill were debated for approximately two years by the Portfolio Committee on Justice and Constitutional Development. The deliberations in Parliament ceased for the politicians to focus on the parliamentary elections in 2004. ${ }^{18}$ The Child Justice Bill was then set aside until 2008. After all the deliberations in the various houses and committees of Parliament, the Bill was finally sent to the president to sign into law. The president signed the Bill during May 2009, with an implementation date set for 1 April 2010. At this stage, the Bill was known as the Child Justice Act 75 of 2008. The reason for the delay in implementation was to give government and civil society time to put mechanisms and machinery in place for the operation of the Child Justice Act.

The preamble to the Child Justice Act stipulates that it was, among others, enacted:

to establish a criminal justice system for children, who are in conflict with the law and are accused of committing offences, in accordance with the values underpinning the Constitution and the international obligations of the republic.

With this in mind, the Child Justice Act sets out an entirely new procedure for children who come into conflict with law, an area that was previously regulated by the Criminal Procedure Act.

The Child Justice Act is a comprehensive piece of legislation that is divided into 14 chapters. The Act also organises offences, according to the seriousness of the committed

16 The late advocate Dullah Omar was previously the director of the Community Law Centre at the University of the Western Cape, where a plethora of research was undertaken into juvenile justice. Upon taking up a position as the Minister of Justice in Nelson Mandela's cabinet, he made it a priority to start the process of creating a criminal justice system that caters for the needs of children who come into conflict with the law.

17 SALRC, Report on Juvenile Justice (Project 106), July 2000.

18 J Gallinetti, "What happened to the Child Justice Bill: the process of law reform relating to child offenders" (2006) 17 South African Crime Quarterly 5. Electronic version on file with the author. 
offence, into three schedules. ${ }^{19}$ Chapter 1 deals with definitions, objects and binding principles of the Act, of which s. 3(i) stipulates that one of the guiding principles of the Child Justice Act which must be taken into account is that the rights and obligations of children with reference to the CRC and the African Charter on the Rights and Welfare of the Child. ${ }^{20}$ Chapter 2 regulates the application of the Child Justice Act, ${ }^{21}$ criminal capacity of children ${ }^{22}$ and matters relating to age, ${ }^{23}$ while chapter 3 sets the procedure in motion for a child who has been charged with committing an offence. ${ }^{24}$

Chapters 4 and 5 respectively deal with the pretrial release and detention of children and their assessment. Chapter 4 was framed with the intention of giving legislative recognition to the South African constitutional and international law provisions which stipulate that children should not be detained, and if detained then it should be only for the shortest appropriate period of time. ${ }^{25}$ Chapter 5 , even though not an entirely new phenomenon in South African law, now regulates the assessment procedure under a comprehensive system of child justice provided by a single statute. ${ }^{26}$

The preliminary inquiry ${ }^{27}$ is a new procedure introduced in chapter 7 of the Child Justice Act. This inquiry takes place before a magistrate with the aim of considering the recommendations made by a probation officer during the assessment. At this stage a matter against a child can either be diverted, or sent to the children's court (if it is found that the child is in need of care and protection), or sent to trial at the Child Justice Court, where a different presiding officer will hear the case against the child. The preliminary inquiry is indeed an innovative procedure that caters for the needs of children, which in itself signifies compliance with Article 40 of the CRC.

Diversion from formal court proceedings is regulated by both chapters 6 and 8 of the Child Justice Act. Chapter 6 allows for prosecutorial diversion for minor offences, contained in Schedule 1 of the Child Justice Act. This procedure would allow a child to be diverted even before attending a preliminary inquiry. ${ }^{28}$ Chapter 8 , in detail, regulates diversion and contains provisions around the types of diversion, ${ }^{29}$ the monitoring of diversion, ${ }^{30}$ and the accreditation of diversion options, ${ }^{31}$ amongst others. Noting that diversion was previously regulated by policy, a legislative regulation is definitely welcomed.

19 Schedules 1, 2 and 3 respectively. The seriousness of the offence, together with the age of the child are two sets of circumstances that would dictate the procedure. E.g. if an 11-year-old boy were to be charged with theft below the value of 1500 South African Rand (a Schedule 1 offence), he could be diverted by a prosecutor before a preliminary inquiry takes place. Whereas, in the case of a 16-year-old boy who had committed treason (a Schedule 3 offence), he would not be able to be diverted before the preliminary inquiry.

20 OAU Doc. CAB/LEG/24.9/49 (1990). This Charter is the regional African Children's Charter that encapsulates the rights of children on the continent. South Africa is a state party to this Charter.

21 S. 4 of the Child Justice Act.

22 Ss. 7-11 of the Child Justice Act.

23 Ss. 12-16 of the Child Justice Act.

24 These are covered in ss. 17-20 of the Child Justice Act.

25 See Article 37(b) of the CRC and s. 28(1)(g) of the Constitution.

26 Previously, the assessment procedure was regulated by the Probation Services Amendment Act 35 of 2002. This Act did not apply to the criminal justice system and only applied as practice in courts.

27 S. 43(1) defines the preliminary inquiry as: "(a) an informal pre-trial procedure which is inquisitorial in nature; and (b) may be held in a court or any other suitable place".

28 S. 41 of the Child Justice Act.

29 S. 53 of the Child Justice Act.

30 S. 57 of the Child Justice Act.

31 S. 56 of the Child Justice Act. 
If a child is not diverted away from formal court proceedings, the matter would proceed to trial as regulated in Chapter 9 of the Child Justice Act. The trial takes place like any other criminal trial, except that the identity of the child should not be published and the proceedings should take place in camera. ${ }^{32}$ The child must enter a plea and is allowed to call witnesses in his/her defence. Chapter 9 also allows for the diversion of the matter at trial, but this should be done before the prosecution concludes its case against the child. ${ }^{33}$

Chapter 10 of the Child Justice Act allows for a broad spectrum of sentencing options, which a presiding officer can use to guide his/her discretion in sentencing a child. Included in these options are community-based sentences, ${ }^{34}$ restorative justice sentences, ${ }^{35}$ fines or alternatives to fines, ${ }^{36}$ and custodial sentences, such as to child and youth care centres ${ }^{37}$ and prisons. ${ }^{38}$ Appeals and review procedures are catered for in Chapter 12 of the Act, ${ }^{39}$ while legal representation for children is regulated in Chapter 11.40 Chapter 13 allows for the expungement of criminal and diversion records for certain offences ${ }^{41}$ and Chapter 14 , amongst other things, provides for general provisions that assist with the implementation of the Act.

\section{Analysis of compliance with international law}

The following section will investigate the extent of compliance by the Child Justice Act with international law in relation to the four key points for discussion raised above. ${ }^{42}$ These are criminal capacity, pretrial release and detention, diversion and sentencing.

\subsection{CRIMINAL CAPACITY}

Criminal capacity finds its authority in Roman law, ${ }^{43}$ and it was previously regulated and shaped by the common law ${ }^{44}$ in SA. At common law the minimum age for criminal responsibility was set at seven years old. Thus, children below the age of seven were considered to be doli incapax. Children between the ages of seven and 14 years were rebuttably presumed to lack criminal capacity. For children aged 14 years or older, an irrebuttable presumption existed that they were considered to possess criminal capacity and be doli capax. The only way children above the age of 14 years could be considered not to possess criminal capacity was if the defence proved that they were mentally incapable of committing an offence, like any other adult. In other words, this would negate the element of criminal capacity in committing an offence.

The CRC does not stipulate any minimum age for criminal responsibility. Article 40(3)(a) stipulates that states parties shall establish "a minimum age below which children shall be presumed not to have the capacity to infringe the penal law". This article should be

32 S. 63(5) of the Child Justice Act.

33 S. 67(1)(a) of the Child Justice Act.

34 S. 72 of the Child Justice Act.

35 S. 73 of the Child Justice Act.

36 S. 74 of the Child Justice Act.

37 S. 76 of the Child Justice Act.

38 S. 77 of the Child Justice Act.

39 Ss. 84-6 of the Child Justice Act.

40 Ss. 80-3 of the Child Justice Act.

41 S. 87 of the Child Justice Act.

42 See section 1 above.

43 J Burchell, Principles of Criminal Law 3rd edn (Lansdowne: Juta 2005), p. 359.

44 The South African common law consists of the legal heritage which SA inherited from the British, as part of being a previous colony of England. 
read with rule 4.1 of the Beijing Rules that stipulates that the minimum age below which children will not have criminal responsibility should not be "fixed at too low an age level, bearing in mind the facts of emotional, mental and intellectual maturity". With this in mind, the Committee set out to interpret what would constitute a fair age below which children could not commit criminal offences in its General Comment No. 10 on juvenile justice. This comment by the Committee relies quite strongly on rule 4.1 of the Beijing Rules, stipulating that "in line with this rule [rule 4.1 of the Beijing Rules] the Committee has recommended States Parties not set a MACR [minimum age of criminal responsibility] at a too low level and to increase an existing low MACR to an internationally acceptable level". 45 The Committee then recommended that the minimum age of criminal responsibility should not be below the age of 12 years. ${ }^{46}$

During the deliberations on the Child Justice Bill, criminal capacity was one of the most contentious issues to be debated. More specifically, the provisions around the minimum age of criminal responsibility were hotly debated. Sloth-Nielsen argues that the reason for this contention was that in practice, the minimum age of criminal responsibility "is inevitably linked to perceptions and preconceptions about serious juvenile crime". ${ }^{47}$ In its report on juvenile justice the SALRC recommended:

The retention of the current Common Law rule that a child who is seven years (or ten years) old, but has not yet turned 14 years, is presumed to be doli incapax, with additional measures, such as the requirement of expert testimony for rebuttal of the presumption, to ensure enhanced protection for such children. ${ }^{48}$

The recommendation, surprisingly, was not clear on whether it would be children between the ages of seven and 14 years or children between the ages of 10 and 14 years who would be presumed doli incapax. Another consequence of this recommendation would therefore seem the acceptance that the irrebuttable presumption of doli capax would still remain against children who were 14 years or older (subject to them not possessing any other mental disability at the time when they committed the offence).

The version of the Child Justice Bill that was debated in Parliament proposed to amend the common law in relation to criminal capacity by stipulating that the minimum age for criminal responsibility should be set at 10 years. ${ }^{49}$ The Child Justice Bill then kept the provisions of the common law by stipulating that children between the ages of 10 and 14 years were rebuttably presumed to be doli incapax. ${ }^{50}$ The Child Justice Bill was also silent on the issue of children above the age of 14 years. Therefore, it was presumed that children above the age of 14 years were irrebuttably presumed to be doli capax, subject to them not possessing any other form of mental disability at the time they committed an offence. 51

The outcome of the Child Justice Act saw no change in what was proposed in the initial Child Justice Bill. Therefore, the South African Parliament did not take the recommendations of the Committee into account when it set the minimum age for criminal

45 Committee on the Rights of the Child, General Comment No. 10: Children's Rights in Juvenile Justice (2007) para. 16. Hereinafter referred to as General Comment No. 10.

46 Ibid.

47 J Sloth-Nielsen, “The juvenile justice law reform process in South Africa: can a children's rights approach carry the day?" (1999) 18 Quinnipiac Law Review 487.

48 SALRC, Report on Juvenile Justice, n. 17 above, p. 25.

49 S. 7(1) of the Child Justice Bill.

50 S. 7(2) of the Child Justice Bill.

51 S. 7(3) of the Child Justice Bill stipulates that "the common law pertaining to the criminal capacity of children under the age of 14 years is hereby amended to the extent set out in this section". This would lead one to then interpret that the common law position of children above the age of 14 years still applies. 
responsibility at 10 years and not 12 years. It did this despite being alerted to the Committee's position during the parliamentary debates. ${ }^{52}$

All is not lost, however. As a result of civil society advocacy, Parliament was under pressure to recognise its obligations in terms of General Comment No. 10 and decided to insert s. 8 into the Child Justice Act which stipulates that:

In order to determine whether or not the minimum age of criminal capacity as set out in section 7(1) should be raised, the Cabinet minister responsible for the administration of justice must, not later than five years after the commencement of this section, submit a report to Parliament...53

Even though this would mean that in five years' time Parliament would have the opportunity to review the minimum age of criminal responsibility and reform it in line with General Comment No. 10, s. 8 does not guarantee that the minimum age would be raised. It stipulates that "in order to determine whether or not", thus a possibility still exists for the minimum age of criminal responsibility to stay the same after five years of implementation of the Child Justice Act.

\subsection{Pretrial release and detention}

The Constitution sets the tone within which pretrial release and detention of children should be interpreted. ${ }^{54}$ It stipulates that every child has the right not to be detained, unless detention is a measure of last resort, in which case such detention has to be for the shortest appropriate period of time. ${ }^{55}$

The Correctional Services Act ${ }^{56}$ regulated children awaiting trial in detention by stipulating that children can only be detained in prison if it is in the interests of justice and there are no places of safety available to detain such children. ${ }^{57}$ Sloth-Nielsen correctly argues that:

52 See submission by the Child Justice Alliance on Child Justice Bill 2008, available at www.childjustice.org.za/submissions/2008Submissions/Child\%20Justice\%20Alliance.pdf.

53 S. 8 of the Child Justice Act. Furthermore, s. 96(4) of the Child Justice Act stipulates what exactly the Minister of Justice and Constitutional Development should highlight in his/her report to Parliament on the review of the minimum age of criminal responsibility, including matters relating to statistics of children who came into contact with the child justice system. Nowhere in this section does it highlight that research of a psychological nature should be taken into account, relating to the development of children's brain activity or cognitive and conative mental functions, which would serve as a more accurate form of assessing the minimum age of criminal responsibility.

54 Before the dawn of the Constitution, the provisions on bail as stipulated in Chapter 9 of the Criminal Procedure Act applied generally to every person accused of committing an offence. Based on the provisions of Chapter 9 of the Criminal Procedure Act, any person accused of committing an offence could apply for bail with the police, upon being arrested; with the National Prosecution Authority; or in court. If bail was not a viable option for a child who had committed an offence, he or she could certainly also have been granted placement either in a place of safety or under the supervision of a probation officer, in terms of s. 71 of the Criminal Procedure Act. S. 72(1)(b) of the Criminal Procedure Act also allowed for a child to be released into the custody of a person with care over the child without requiring any form of bail. This section has been repealed by the Child Justice Act.

55 S. 28(1)(g) of the Constitution states that: "Every child has the right not to be detained except as a measure of last resort, in which case, in addition to the rights a child enjoys under sections 12 and 35, the child may be detained only for the shortest appropriate period of time, and has the right to be - (i) kept separately from detained persons over the age of 18 years; and (ii) treated in a manner, and kept in conditions, that take account of the child's age."

56 Act 8 of 1959.

57 S. 29 of the Correctional Services Act. S. 29 was an amendment to the Correctional Services Act that was passed during 1997. 
there was no requirement that the decision to detain a child in prison take account of the best interests of the child concerned, nor was the criterion that detention in prison must be considered "necessary in the interests of justice" linked in any way to the seriousness of the offence, to the possibility of danger to society, or to any other test that could give effect to the notion that detention in prison be used sparingly. ${ }^{58}$

Thus the provisions that existed then were somewhat unfortunate, as the consequences thereof would have seen children detained without taking their interests into account. This notwithstanding the fact that this amendment (i.e. s. 29) was temporary, as it was foreseen that the then Child Justice Bill would pass through Parliament relatively soon thereafter.

The JDL Minimum Standards set the framework for the interpretation of Article 37(b) of the CRC, by stating that "detention before trial shall be avoided to the extent possible and limited to exceptional circumstances". ${ }^{59}$ The Beijing Rules document, on the other hand, is more specific as it states that police officials must be trained in dealing with children who come into contact with the justice system. ${ }^{60}$ One can certainly argue that this would also apply to training police officials on the propriety of arresting children. Paragraph 10.2 of the Beijing Rules also states that "a judge or other competent official or body shall, without delay, consider the issue of release".

Article 37 of the CRC stipulates the provisions within which detention (which includes pretrial detention) should take place. Section 28(1)(g) of the Constitution is framed along the same lines as Article 37 of the CRC. The latter stipulates that:

No child shall be deprived of his or her liberty unlawfully or arbitrarily. The arrest detention or imprisonment of a child shall be in conformity with the law and shall be used only as a measure of last resort and for the shortest appropriate period of time. ${ }^{61}$

This article thus calls on states parties to the CRC to enact laws that would see practitioners, like police officials, prosecutors and magistrates, exercise a workable discretion on how to implement the detention of children as a measure of last resort. Together with that, states also have to enact legislation that would ensure that, should children be detained, it is for the shortest appropriate period of time. When examining the international framework where pretrial release and detention is regulated, it is interesting to note that there is no specified age stipulated for the detention of children in prison. ${ }^{62}$

With the dawn of the Child Justice Act in SA, pretrial release and detention is now regulated before and after a pretrial procedure called the preliminary inquiry. Upon being suspected of committing an offence, a child may not be arrested by a police official for committing a Schedule 1 offence, ${ }^{63}$ unless certain circumstances exist as stipulated in the

58 J Sloth-Nielsen, The Role of International Law in Juvenile Justice Reform in South Africa (unpublished LLD Thesis, University of the Western Cape, Cape Town 2001), p. 166.

59 Para. 17 of the JDL Minimum Standards.

60 Para. 12.1 of the Beijing Rules.

61 Article $37(\mathrm{~b})$ of the CRC.

62 Sloth-Nielsen, The Role of International Law, n. 58 above, p. 162.

63 The offences in the Child Justice Act are organised in three schedules annexed to the Act. Schedule 1 offences are the least serious and examples of these include theft below the value of 2500 South African Rand (equivalent to approximately US $\$ 375$ at the time of writing) and common assault. For a list of offences see Schedules 1, 2 and 3 annexed to the Child Justice Act. 
Child Justice Act. ${ }^{64}$ Instead, the Child Justice Act requires that a police official return the child to his/her home and hand to a parent/guardian/appropriate adult a written notice indicating when the child should appear at court. ${ }^{65}$ Where a child has been arrested for either committing a Schedule 1 or 2 offence, ${ }^{66}$ the prosecutor has the authority to release a child on bail. ${ }^{67}$ For committing a Schedule 3 offence, a child cannot be released before attending the preliminary inquiry, as s. 21(3)(a) reads that a presiding officer can release a child into the care of his/her parents where the child is accused of committing any offence. With that said, it therefore follows that a child who has committed a Schedule 3 offence 68 will be detained before attending the preliminary inquiry. Even though, in essence, the Child Justice Act is centred on not detaining a child before he or she has to appear before court, ${ }^{69}$ it does make allowance for the detention of children who have committed an offence. This seems to highlight the intention of the drafters to uphold the "last resort" detention principle. The qualifying question would be: what constitutes "the shortest appropriate period of time"?

In SA, every person accused of committing an offence has to appear before a court within 48 hours of being arrested. ${ }^{70}$ This rule also applies to children. ${ }^{71}$ In General Comment No. 10, the committee recommended that every child who is arrested should be brought before "a competent authority to examine the legality of (the continuation of) this deprivation of liberty within 24 hours". ${ }^{72}$ This requires that a child be brought before somebody who has the capacity to examine solely the issue of whether the child should remain further in detention or not. This examination should therefore not delve into the merits of the case. The Committee did not explicitly stipulate that it has to be a court. It could, therefore, even be persons who work for the prosecuting authority. The Child Justice Act merely stipulates that upon the arrest of a child, the police official should notify a probation officer of this arrest within 24 hours. ${ }^{73}$ The probation officer does not have the authority to examine the legality of a child's deprivation of liberty. The officer can only make a recommendation of such deprivation to an inquiry magistrate ${ }^{74}$ to consider at the preliminary inquiry. Thus, the Child Justice Act does not contain any provision that would cater for the immediate examination of the legality of a child's deprivation of liberty in order to ensure that, if it is not acceptable, such a child should be released immediately.

64 S. 20(1) of the Child Justice Act. Some of these circumstances include where a police official has reason to believe that a child might not have a fixed address or where the police official believes that the child will continue to commit the offence.

65 S. 21(2)(a) of the Child Justice Act.

66 Some examples of Schedule 2 offences include theft where the value exceeds 2500 South African Rand (equivalent to approximately US\$375 at the time of writing), public violence and culpable homicide.

67 S. 21(2)(b) of the Child Justice Act.

68 Some examples of Schedule 3 offences include treason, murder, kidnapping and rape.

69 See Gallinetti who correctly argues that the Child Justice Act should be interpreted with due regard to the least restrictive option possible when detaining a child. Thus, if a child should be detained, he or she must first be considered to be interned in a child and youth care centre, then a police cell (but only prior to the child's first appearance at a preliminary inquiry), and then placement in a prison. - J Gallinetti, "Child justice in South Africa: the realisation of the rights of children accused of crime" in T Boezaart (ed.), Child Law in South Africa (Claremont: Juta 2009), p. 659.

70 S. $50(1)$ (c) of the Criminal Procedure Act.

71 S. $20(5)$ of the Child Justice Act.

72 General Comment No. 10, para. 28b.

73 S. 20(4)(a) of the Child Justice Act.

74 An "inquiry magistrate" is defined as: "the judicial officer presiding at a preliminary inquiry". 
Section 33 of the Child Justice Act stipulates that children may not be held in leg-irons and are only to be handcuffed in exceptional circumstances. ${ }^{75}$ The Child Justice Act also requires that children in detention must be separated from adults and that boys be separated from girls. ${ }^{76}$ The Child Justice Act is thus certainly in compliance with Article 37(c) of the CRC which requires children who are deprived of their liberty to be "treated with humanity and respect" and "to be separated from adults unless it is considered in the best interest of the child not to do so". However, a contentious provision which found its way into the Child Justice Act relates to the transportation of children who are detained. The Child Justice Act stipulates that children must be transported to court separately from adults, provided that it is possible to do so. The Child Justice Act requires a police official to give reasons to a presiding officer (within 48 hours) on why he or she transported children with adults. ${ }^{77}$ Deprivation of liberty should be interpreted broadly to not only include the detention of children, but also the transportation of children who are detained. The only manner in which the proviso in relation to transporting children with adults can comply with the $\mathrm{CRC}$ is if it is in the best interests of children to do so. As far as transporting children with adults is in their best interests, s. 33(2)(c) of the Child Justice Act should be interpreted narrowly, as recommended by the Committee. ${ }^{78}$

\subsection{DIVERSION}

The third provision to be examined is in relation to the diversion of children away from formal court procedures. Although not an entirely new phenomenon in SA, ${ }^{79}$ diversion is for the first time given legislative recognition in the Child Justice Act, as part of an overarching child justice system. ${ }^{80}$

In a research study conducted by the Child Justice Alliance, ${ }^{81}$ Gallinetti and Kassan found that diversion had inconsistent application across three magisterial districts in SA before the coming into force of the Child Justice Act. ${ }^{82}$ This inconsistent application of diversion related to the fact that, in one magisterial district of the study, diversion was recorded on the charge sheet, while in the other two it was inconsistently recorded or children were hardly diverted away from the criminal justice system. ${ }^{83}$ The authors here correctly argue that a legislative framework was needed in order to ensure consistency of practice for diversion. ${ }^{84}$

75 S. 33(1) of the Child Justice Act.

76 S. 33(2) (a) and (b) of the Child Justice Act.

77 S. 33(2)(c) of the Child Justice Act.

78 General Comment No. 10, para. 28c.

79 Gallinetti, "Child justice", n. 69 above, p. 642, states that: "In South Africa, diversion services have been offered since the beginning of 1990s." In the case of $S_{\mathrm{V}} Z$ en vier ander sake 1999 (1) SACR 427 (E), diversion also received judicial approval by the High Court, even in the absence of a legislative framework for it - see p. 429 , para. b.

80 Previously, diversion was given legislative recognition in the Probation Services Amendment Act 35 of 2002 , where it applied in general to any person who can be diverted.

81 The Child Justice Alliance is a network of over 400 non-governmental organisations and friends in SA working on child justice issues. The alliance was initially created to see one civil society movement back the passing of the then Child Justice Bill through Parliament. Considering that the Child Justice Bill has been enacted, the Child Justice Alliance will now focus on research and advocacy around the implementation of the Child Justice Act. See www.childjustice.org.za, for further details on the Child Justice Alliance.

82 J Gallinetti and D Kassan, Child Justice Alliance: A baseline study of children in the criminal justice system in three magisterial districts (Cape Town: Child Justice Alliance 2007), p. 30.

83 Ibid.

84 Ibid. 
The Beijing Rules place an obligation on the police or the prosecution or any other agency to have the competency to divert a matter. ${ }^{85}$ The Beijing Rules also stipulate the following requirements necessary in order for diversion to succeed:

i. the necessary consent of the child, or his or her parents/guardians; and

ii. a competent authority to review cases that are diverted. ${ }^{86}$

Article 40(3)(b) of the CRC, which should be interpreted in line with the Beijing Rules, sets the standard for the establishment of diversion programmes by requiring states parties to:

Whenever appropriate and desirable, [enact] measures for dealing with such children [who come into conflict with the law] without resorting to judicial proceedings, providing that human rights and legal safeguards are fully respected.

An important international requirement that needs to be emphasised relates to the significance of ensuring that a competent review mechanism of diverted matters is in existence. Diversion essentially means that a child accused of an offence would admit to having committed such an offence and therefore his/her due process rights - e.g. the right to be presumed innocent until proven guilty by a court of law and the right to remain silent - might be compromised in order to ensure that the matter does not end up in court. ${ }^{87}$ General Comment No. 10 creates a protective mantle for children by recommending that states parties to the CRC must ensure that:

[a] child must be given the opportunity to consult with legal or other appropriate assistance on the appropriateness and desirability of the diversion offered by the competent authorities, and on the possibility of review of the measure. ${ }^{88}$

Sloth-Nielsen therefore highlights the following three important reasons why diversion should be regulated in law. She first states that because of its informal nature, a decision to divert a matter will not be subject to judicial scrutiny without legislative recognition. ${ }^{89}$ Secondly, she notes that evidence shows that, for historical reasons, there exist wide discrepancies about its practice and the lack of regulation would not see prosecutorial or police policy in this regard subject to parliamentary scrutiny..$^{90}$ Her third and probably most important argument (for this article) for why diversion should be regulated is to ensure that legal safeguards are fully respected as required by Article 40(3)(b) of the CRC. ${ }^{91}$

During the law reform process on child justice in SA, the SALRC was certainly correct in stipulating that a legislative framework should exist that would ensure that children benefit from diversion options. ${ }^{92}$ More importantly, it was also correct when it emphasised that the approach to diversion should be an "innovative and imaginative" one. 93 Thus, a level of flexibility with a judgment on a case-by-case basis would be the considered approach. Sadly, this flexibility was not favoured by the deliberations in Parliament and a somewhat over-regulated system was adopted by Members of Parliament. This in essence

85 Para.11.2 of the Beijing Rules.

86 Para.11.3 of the Beijing Rules.

87 Skelton highlights this as "a view that restorative justice practice [diversion being one aspect of it] may erode due process rights such as the right to remain silent and the right to be considered innocent until proven guilty. These fundamental elements [she argues] may be placed at risk by a tendency to coerce children to admit guilt in order to be considered for diversion to restorative justice options.": A Skelton "Restorative justice as a framework for juvenile justice reform: a South African perspective" (2002) 42 British Journal of Criminology 506.

88 General Comment No. 10, para. 13.

89 Sloth-Nielsen, The Role of International Law, n. 58 above, pp. 251 and 252.

90 Ibid. p. 252.

91 Ibid.

92 SALRC, Report on Juvenile Justice, n. 17 above, p. 99.

93 Ibid. pp. 99 and 100. 
would lead to cases where diversion cannot be considered as a preferred approach and, therefore, the desirability of diverting a case away from the criminal justice system (as encapsulated by Article 40(3) of the CRC) is lost.

The Child Justice Act organises diversion into two levels, the first being for less serious offences than the second. ${ }^{94}$ The Child Justice Act allows for diversion to take place at three stages in the child justice system. Firstly, a prosecutor would have the competency to divert a case to a level one diversion option, where the child committed a Schedule 1 offence. ${ }^{95}$ Secondly, an inquiry magistrate can order that a child be diverted at the preliminary inquiry, after the necessary consent has been granted by the National Prosecuting Authority. ${ }^{96}$ Lastly, a matter can be diverted at the trial in the Child Justice Court, at any time before the close of the prosecution's case against a child. ${ }^{97}$ The Child Justice Act is also very clear that a prosecutor would have to consent that a Schedule 2 matter can be diverted ${ }^{98}$ and the Director of Public Prosecution would have to consent for Schedule 3 matters to be diverted. ${ }^{99}$

The Child Justice Act does not create any mechanism for the review of a decision to divert a case (as required by para. 11.3 of the Beijing Rules), especially in relation to diversion for a Schedule 1 offence by the prosecutor. It is envisaged in the Child Justice Act that this type of diversion would normally happen before a child appears before a magistrate and therefore the Child Justice Act had at a minimum to create review mechanisms for diversions in cases of this nature. Such review mechanisms would protect children against being coerced into admitting responsibility for committing the offence and would also be a suitable option to ensure that a child's right to silence was respected, together with his or her presumption of innocence.

Even though diversion is now correctly embedded in legislation, the question still remains whether the over-regulation thereof, together with the lack of proper review mechanisms, will comply with the innovative nature of diversion and international principles, as stipulated in the CRC and the Beijing Rules.

\subsection{SENTENCING}

The fourth and final topic which this article examines relates to sentencing of children convicted of offences. Preceding the CRC and the Child Justice Act, the common law, by way of judicial precedent, has always acknowledged that adolescence is a mitigating factor when sentencing a child. ${ }^{100}$ At the same time, the death penalty was also a possible sentence to be imposed on a child who committed a heinous offence, like murder. ${ }^{101}$ Corporal

94 S. 53(3) of the Child Justice Act highlights the various level one diversion options, while s. 53(4) highlights level two diversion options.

95 S. 41 of the Child Justice Act.

96 S. 52 of the Child Justice Act.

97 S. 67 of the Child Justice Act.

98 S. 52(2) of the Child Justice Act states that this can only happen once the prosecutor has consulted with the victim, where it is possible to do so, and the police investigator.

99 S. 52(3) of the Child Justice Act stipulates that the Director of Public Prosecutions, who has jurisdiction, can only do this once he or she has consulted with the victim, where it is possible to do so, and the police investigator.

100 For example, see $S$ v Lehnberg en 'n ander 1975 (4) (SA) 553 (A) where the then Appellate Division of the Supreme Court held that it goes without saying that degrees of adulthood exist among teenagers, but the ripeness of being an adult might be absent. Adolescence does not constitute adulthood (p. 561 A-B) (translated by the author from Afrikaans). See also Sloth-Nielsen, The Role of International Law, n. 58 above, pp. 375-5 for an in-depth explanation of the history in relation to the sentencing of children.

101 Sloth-Nielsen, The Role of International Law, n. 58 above, pp. 377-8. 
punishment was also an accepted and often used form of punishment for children convicted of an offence. ${ }^{102}$ Thus, even though adolescence could serve as a mitigating factor for sentencing a child, it was still possible to sentence a child to the gallows or cane him or her. This certainly amounted to an unfortunate juxtaposition in South African law.

The Criminal Procedure Act was the statute that regulated the different types of sentences available to presiding officers when exercising their discretion to impose sentences on children. Section 290 of this Act provided the following three options for sentencing, other than that of imprisonment:

(a) placement under the supervision of a probation/correctional officer;

(b) placement under the custody of a suitable person; or

(c) a sentence to a reform school.

This certainly served as a notable attempt by the South African Parliament to impose sentences of a nature other than imprisonment or caning children. However, it remains questionable whether the sentence to a reform school was in compliance with international law. Sloth-Nielsen has raised a concern over this sentence, as it was normally imposed on a child for a period of two years, which could be extended by the then Minister for Welfare and Population Development until the child turned 18 or even 21 years of age. ${ }^{103}$

The Constitution also contributed to the overall sentencing environment through s. 28(1)(g), which called for detention of children to be used as a measure of last resort and stipulated that if detention should occur then it should be for the shortest appropriate period of time. ${ }^{104}$

Article 40(4) of the CRC stipulates very broadly that a range of alternatives should be considered before institutionalising a child. ${ }^{105}$ This same article also requires that a proportionate approach should be adopted between the circumstances of the child and the offence committed. This proportionate approach certainly should serve as a major factor in pronouncing a sentence upon a child. Article 40(4) of the CRC should also be read with Article 37, where it stipulates that the imprisonment of children should be used a measure of last resort and for the shortest appropriate period of time. ${ }^{106}$ Article 39 of the $\mathrm{CRC}$ requires states parties to enact measures that would promote the social reintegration of children. The scope of Article 39 is broad enough to call on states to enact measures of social reintegration of children who were sentenced for committing an offence, especially children who were sentenced to a custodial setting. The Beijing Rules also highlight a large variety of possibilities available that would not see a child sentenced to a custodial setting, namely; community service orders, fines and compensation, and counselling orders, among other measures. ${ }^{107}$ Rule 19 more importantly highlights that

102 In the case of $S_{\mathrm{V}}$ Williams and Others CCT/20/94 the Constitutional Court found that ss. 294 and 290(2) of the Criminal Procedure Act were inconsistent with the Interim Constitution of the Republic of SA 200 of 1993. These sections allowed for a child to be "whipped" as a form of punishment for committing an offence. The judgment in this case was handed down before the law reform process started in SA.

103 Sloth-Nielsen, The Role of International Law, n. 58 above, p. 380.

104 See section 4.2 above.

105 Article 40(4) reads: "A variety of dispositions, such as care, guidance and supervision orders; counseling; probation; foster care; education and vocational training programmes and other alternatives to institutional care shall be available to ensure that children are dealt with in a manner appropriate to their well-being and proportionate both to their circumstances and the offence."

106 Article 37(b) reads: "No child shall be deprived of his or her liberty unlawfully or arbitrarily. The arrest, detention or imprisonment of a child shall be in conformity with the law and shall be used only as a measure of last resort and for the shortest appropriate period of time."

107 See rule $18.1(\mathrm{a})-(\mathrm{h})$. 
"the placement of a juvenile in an institution shall always be a disposition of last resort and for the minimum necessary period".

With this in mind, Sloth-Nielsen correctly highlights the following three important international principles that should serve as a foundation for a judicial officer when considering imposing a sentence on a child: (1) "the injunction that detention must be considered only as a last resort and for the shortest period of time"; 108 (2) "the principle of proportional and individualised responses to offending"; 109 and (3) "the emphasis on preparing the child offender for his or her return to society where detention has ultimately been deemed necessary". 110

During the law reform process, the SALRC came to the proposition that retributive sentences should be kept to a minimum, as it "would upset the balance between [the] offender, [the] victim and [the] community". 111 This was certainly a noble approach that is in compliance with Article 37 of the CRC and rule 19 of the Beijing Rules. ${ }^{112}$

The Child Justice Act lists the following five objectives of sentencing:

(a) encourage the child to understand the implications of and be accountable for the harm caused;

(b) promote an individualised response which strikes a balance between the circumstances of the child, the nature of the offence and the interests of society;

(c) promote the reintegration of the child into the family and community;

(d) ensure that any necessary supervision, guidance, treatment or services which form part of the sentence assist the child in the process of reintegration; and

(e) use imprisonment only as a measure of last resort and only for the shortest appropriate period of time. ${ }^{113}$

The formulation of these objectives is certainly in compliance with international law to the extent that it encapsulates the three principles highlighted by Sloth-Nielsen, being to use the detention of children as a last resort, using a proportional approach to sentencing, and placing an emphasis on the reintegration of the child back into the community. An added and certainly necessary addition to the objectives of sentencing in SA relates to holding the child accountable for the harm that he or she has caused. However, it has to be emphasised that the manner in which this objective would be sought should be in compliance with the best interests of the child principle.

The Child Justice Act also permits a presiding officer to take a number of factors into account when sentencing a child to a custodial setting which include the seriousness of the offence and whether the harm caused would require that a child be sentenced to a residential setting. ${ }^{114}$ The Child Justice Act allows a prosecutor to produce evidence of a witness impact statement during sentencing proceedings ${ }^{115}$ and requires that probation

108 J Sloth-Nielsen, "Juvenile sentencing comes of age” (2005) 1 Stellenbosch Law Review 100.

109 Ibid.

110 Ibid.

111 SALRC, Report on Juvenile Justice, n. 17 above, p. 162.

112 See also Sloth-Nielsen, The Role of International Law, n. 58 above, p. 364, who states that: "The proposals for juvenile justice reform that were advanced by the South African Law Commission [in relation to sentencing] were shaped by CRC and the Beijing Rules."

113 S. 69(1) of the Child Justice Act.

114 See s. 69(3) and (4) that creates a distinction between factors to be considered for sentences of imprisonment and to a child and youth care centre respectively.

115 See s. 70 of the Child Justice Act. 
officers provide the court with pre-sentence reports in which the probationer officer can make a recommendation on the sentence to be imposed on a child. ${ }^{116}$

Lastly, the Child Justice Act allows for a list of innovative sentencing options that can be imposed on a child including: community-based sentences ${ }^{117}$ restorative justice sentences; ${ }^{118}$ fines or alternatives to fines; ${ }^{119}$ sentences involving correctional supervision; ${ }^{120}$ sentences to a child and youth care centre; ${ }^{121}$ and, finally, sentences to prison. ${ }^{122}$

The Child Justice Act is very clear that children below the age of 14 years at the time of sentencing may not be sentenced to prison. ${ }^{123}$ Gallinetti correctly criticises this provision by warning that the National Prosecuting Authority may at times delay prosecuting children below the age of 14 years to ensure that a child may be eligible to be sentenced to prison. ${ }^{124}$ This would essentially be in contradiction with the best-interests of the child principle, as it would not ensure that a trial is speedily completed against a child, and also that strategic and tactical loopholes make it possible to have a child sentenced to prison.

Section 77 of the Child Justice Act also creates a maximum time period that a child can be sentenced to prison by stipulating that children can be sentenced to imprisonment "for a period not exceeding 25 years". ${ }^{25}$ Once again Gallinetti warns that the express mentioning of a maximum period could support a presiding officer (who has a discretion to pronounce a sentence) to impose a sentence that is lengthier than would have been imposed in the past. ${ }^{126}$ She therefore rightly concludes that it would have been preferable if the Child Justice Act had remained silent on the period that a child can be sentenced to prison. ${ }^{127}$

\section{Conclusion}

The title of this article poses the question whether SA complies with its obligations in terms of children's rights. The use of just four topics in this chapter might not be enough to measure SA's compliance in totality, but these four topics certainly play an important role in establishing whether the basic legal rights and standards of children who come into conflict with the law are in conformity with international law.

The answer to this research question is not a clear "yes". As can be seen from the analyses above, there are instances where SA does comply with international law through the final provisions of the Child Justice Act. The Child Justice Act raised the minimum age of criminal responsibility from seven years to 10 years; it legislated the principle that children should not be detained and, if they are, it should be for the shortest period of time; diversion in SA now has a legislative existence; and a range of sentencing options are available, other than sentencing a child to a reform school or prison.

116 See s. 71 of the Child Justice Act.

117 See s. 72 of the Child Justice Act.

118 See s. 73 of the Child Justice Act.

119 See s. 74 of the Child Justice Act.

120 See s. 75 of the Child Justice Act.

121 See s. 76 of the Child Justice Act.

122 See s. 77 of the Child Justice Act.

123 See s. 77(1)(a) of the Child Justice Act.

124 Gallinetti, "Child justice”, n. 69 above, p. 662.

125 See s. 77(4) of the Child Justice Act. During 2007, Parliament enacted the Criminal Law (Sentencing) Amendment Act, which brought about the option of imposing minimum sentences on children in the age category of 16 and 17 years old. The Constitutional Court found this legislation to be unconstitutional in the case of Centre for Child Law v Minister of Justice and Constitutional Development and Others CCT 98/08.

126 Gallinetti, “Child justice”, n. 69 above, p. 662.

127 Ibid. 
It is somewhat unfortunate, however, that there are technical aspects of the Child Justice Act that are not truly in compliance with international law and principles. The Child Justice Act does not stipulate that the minimum age of criminal responsibility should be 12; instead it provides for criminal responsibility at 10 years of age. There is no stipulation in the Child Justice Act that requires, within 24 hours from being detained, that a child's detention is reviewed by a competent authority. Provisions relating to the review of a decision to divert a child are also not catered for, especially those that relate to the diversion of a child by a prosecutor before the child's first appearance at a preliminary inquiry. No provision exists that would require the prosecution not to delay proceedings against a child in order to make sure that the child is 14 years or older, at the time of sentencing, in order to secure a prison sentence.

Therefore, it can be concluded that SA has taken considerable steps to ensure that its relatively new child justice system is compliant with international law and its constitutional provisions. However, the new child justice system is not ideal, as it allows for lacunae which would not be in a child's best interests. This certainly opens the scope for strategic litigation on the constitutionality of the Act and compliance with international obligations which are enforceable in South African courts. 